\title{
REHABILITATION OF PERSONS WITH HEARING IMPAIRMENT IN OBIO/AKPOR LOCAL GOVERNMENT AREA OF RIVERS STATE, NIGERIA: IMPLICATION FOR SPECIAL NEEDS COUNSELLING
}

\author{
Ubani, N. Samuel ${ }^{1}$, \\ Okiridu Ngozi², \\ Iroegbu Ferdinand Favour ${ }^{3 i}$ \\ ${ }^{1} \mathrm{PhD}$, Special Education Unit, \\ Department of Educational Psychology, \\ Guidance and Counselling, \\ Ignatius Ajuru University of Education, \\ Rumuolumeni, Port Harcourt, \\ Nigeria \\ 2PhD, Department of Educational Psychology, \\ Guidance and Counselling, \\ Ignatius Ajuru University of Education, \\ Rumuolumeni, Port Harcourt, \\ Nigeria \\ ${ }^{3}$ Cherry Pearl Foundation School, \\ \#9 New Road Mgbouba Port Harcourt, \\ Nigeria
}

\begin{abstract}
:
This study aimed to determine the experiences of pre-service teachers in teaching students with special needs during the practicum. To achieve this goal, the study was designed as descriptive research within the framework of the qualitative research paradigm. The participants were 11 pre-service teachers who had students with special needs during their practicum process. Pre-service teachers were studying in different departments of the faculty of education. The students with special needs were in different disability groups such as visual impairment, physical disability, and autism spectrum disorders. To identify pre-service teachers' experiences in teaching students with special needs, semi-structured interviews were conducted in the fall semester of the 2021-2022 academic year. The data were analyzed through content analysis. Based on the findings, it can be stated that pre-service teachers needed to be supported regarding individuals with special needs and how to teach these individuals. Besides, although some of the preservice teachers were supported by mentors, others were not.
\end{abstract}

'Correspondence: email samuelubani22@gmail.com, stacyclement@yahoo.com, favouriroegbu26@gmail.com 
Keywords: rehabilitation, academic performance, quality of social interaction, hearing impairment

\section{Introduction}

The basic philosophy of Nigerian education emphasizes integrating the individual into a sound and effective citizen by providing educational opportunities from primary to the tertiary level. Since the mid-1960s, Government's commitment has been the use of education as a tool for social change and for national development (Sani, 2015). The education of persons with special needs has been categorized into different stages ranging from sheltered workshops, segregated placement alternatives, integration, mainstream, resource room services, and so forth. With the present call on the total restoration of students with special needs, efforts are being made to get students with hearing impairment rehabilitated; which is one of the major thrusts of special education as posited by (Kinanee \& Ubani 2019). As Ubani et al., (2020) will put it, that children's success in life depends on the preparation they get both at home and in school settings. Over the years, there have been various forms of educational service provisions for children with hearing impairment. It was revealed by Ubani et al., (2020) that most rehabilitation programs for persons with hearing loss have provisions for counselling services.

Similarly, Ubani and Sanikpege (2020) noted that some children are born with hearing loss while others develop hearing loss at some time. Ubani and Sanikpege (2020) added that many children have a mild hearing loss while some have severe or profound hearing loss. Similarly, Ubani and Sanikpege (2020) noted that there are no reliable data in Nigeria about how many children have hearing impairments, but special education resource centre workers have suggested that up to $50 \%$ of students could have some hearing impairment in many areas. Hence, teachers should expect to have some students with mild and moderate hearing impairments in their classes. In the opinion of Ubani and Sanikpege (2020) hearing impairment was deduced as a limitation in sound perception. However, Ozoji (2003) referred to students with impaired hearing as children/students in whom the sense of hearing is defective and this could range from the ability to hear partially to total deafness.

Historically, it was believed that since the population of this category of persons was negligible, the best way to carry them along was to attend to them separately. The rationale may seem correct but in practice, it was detrimental to the students with impaired hearing. In addition, in the special schools, most of the learning inputs were inadequate and inappropriate. Hence the students with hearing impairment were considered unteachable. Moreover, since this category of students has been labelled as being unable to learn, it was believed that any teacher would do, even if the teachers are inexperienced and untrained (Obani, 2006). In response to the restriction imposed on persons with hearing impairment in function, perception, academic performance and social acceptance, Nanjwan and Plang (2014) retaliated that this can lead to high levels of 
frustration due to the unmet needs of the client. Most students with hearing impairment have been poorly served by rehabilitation service providers in many ways. The volume of services lacked expertise and reliable technology. Most persons with hearing impairment have either had no access to a solution or have experienced a poor outcome. However, there has been an emergence of improved services and accessibility to international products that can aid in rehabilitating persons with hearing impairment. Dunlop (2005) cited in Nanjwan and Plang (2014) noted that the provision of rehabilitation for persons with special needs requires different rehabilitation process.

It was for this reason that, Ozoji (1993) explained rehabilitation to be the process that leads to the restoration of the disabled to the fullest physical mental, social, vocational and economic usefulness of which they are capable to achieve. It can be seen that without rehabilitation, the education of a person with special needs may likely be affected in negative ways. The rehabilitation process is different for everyone depending on the impairment and the needs of the individual. Rehabilitation programmes should be individualized, catering to each person's unique needs because no two deformities are exactly alike (Nanjwan \& Plang, 2014). Contributing, Ihenacho (2010) maintained that the provision of service to persons with special needs can be done by different categories of people such as: the government, community, private organization, and individuals. Nanjwan and Plang (2014) narrated that rehabilitation channels the body to natural healing abilities and the brain's relearning processes so that an individual gets relieved as quickly and efficiently as possible; rehabilitation involves learning new ways to compensate for abilities that have permanently changed and finally, the goal of rehabilitation is to help people regain the most independent level of functioning.

\section{Statement of the Problem}

Significant changes are taking place in society's attitude towards persons with disability. Persons with hearing impairment were once regarded as objects of pity and charity, persons with hearing impairment are now able to become more productive by tapping their residual abilities and faculties through rehabilitation. It is clear that if the outcome of rehabilitation is poor in the state, it can impose hearing aids that have limited use and are inconvenient to the hearing impaired learner. Rehabilitation ought to be addressed by the coordinated involvement of various special, medical, and paramedical professionals for the total restoration of an individual with hearing impairment. The financial cost of securing rehabilitation services can be hard on students with hearing impairment from low-income households, the high cost of rehabilitation facilities, as well as the shortage of such facilities, equipment, and personnel, may have a negative impact on rehabilitation activities of persons with hearing impairment.

The rehabilitation duration period if it takes a longer period will delay the students with hearing impairment from participating with their peers, the lack of proper and timely diagnosing of hearing loss creates an additional problem for the student with hearing impairment and affects the type of rehabilitation that is most appropriate for the 
individual, there is also the need for regular and continuous care, maintenance and adjustment to accommodate changes to lifestyle demands and environment, the change in the rehabilitation service provider may also pose a challenge as new professionals assigned to the child may take long acclimatizing to the onset of the problems, the adaptability of the students to available rehabilitative devices and services becomes another issue of concern. It hence becomes imperative to investigate the relationship that may exist between rehabilitation and persons with hearing impairment in Obio/Akpor Local Government Area of Rivers State.

\subsection{Aim and Objectives of the Study}

Generally, the study seeks to examine the rehabilitation of persons with hearing impairment in Obio/Akpor Local Government Area of Rivers State. Specifically, the study intends to:

1) Determine the relationship between rehabilitation and academic performance of persons with hearing impairment in Obio/Akpor Local Government Area of Rivers State.

2) Find out the relationship between rehabilitation and quality of social interaction of persons with hearing impairment in Obio/Akpor Local Government Area of Rivers State.

\subsection{Research Questions}

The following research questions were posed to guide the conduct of the study

1) What is the relationship between rehabilitation and academic performance of persons with hearing impairment in Obio/Akpor Local Government Area of Rivers State?

2) What is the relationship between rehabilitation and quality of social interaction of persons with hearing impairment in Obio/Akpor Local Government Area of Rivers State?

\subsection{Hypotheses}

The following hypotheses were tested at 0.05 level of significance.

1) There is no significant relationship between rehabilitation and academic performance of persons with hearing impairment in Obio/Akpor Local Government Area of Rivers State.

2) There is no significant relationship between rehabilitation and quality of social interaction of persons with hearing impairment in Obio/Akpor Local Government Area of Rivers State.

\section{Significance of the Study}

The provision of timely and quality rehabilitation service for a person with hearing impairment by well-trained and passionate special educators, medical and paramedical 
professionals has become necessary as it significantly affects their academic and quality of social interaction. This study will be of benefit to special educators, social workers, students with hearing impairment, researchers, policy makers, and the general public. As we strive through creating an enabling environment through rehabilitation that will guarantee a well-adjusted, and functional student with hearing impairment, who will be duly restored in having high-class social interaction and capability, improved social confidence, and academic performance.

\subsection{Scope of the Study}

The study is delimited to students with hearing impairment in Obio/Akpor Local Government Area of Rivers State.

\subsection{Conceptual Framework}

\subsubsection{Rehabilitation}

Rehabilitation has long lacked a unifying conceptual framework. Historically, the term has described a range of responses to disability, from interventions to improve body function to more comprehensive measures designed to promote inclusion. For some people with disabilities, rehabilitation is essential to being able to participate in education, labour market, and civic life. Rehabilitation is always voluntary, and some individuals may require support with decision-making about rehabilitation choices. In all cases rehabilitation should help to empower a person with a disability and his or her family. Maceh (2018) noted that the Habilitation and Rehabilitation, of the United Nations Convention on the Rights of Persons with Disabilities calls for: appropriate measures, including through peer support, to enable persons with disabilities to attain and maintain their maximum independence, full physical, mental, social and vocational ability, and full inclusion and participation in all aspects of life. Maceh (2018) further called on countries to organize, strengthen, and extend comprehensive rehabilitation services and programs, which should begin as early as possible, based on the multidisciplinary assessment of individual needs and strengths, including the provision of assistive devices and technologies. This chapter examines some typical rehabilitation measures, the need and unmet need for rehabilitation, barriers to accessing rehabilitation, and ways in which these barriers can be addressed.

It needs to equip them to live their lives, fulfil their maximum potential and optimize their contribution to family life, their community, and society as a whole. Rehabilitation achieves this by focusing on the impact that the health condition, developmental difficulty, or disability has on the person's life, rather than focusing just on their diagnosis. It involves working in partnership with the person and those important to them so that they can maximize their potential and independence and have choice and control over their own lives. It is a philosophy of care that helps to ensure people are included in their communities, employment, and education rather than being isolated from the mainstream and pushed through a system with ever-dwindling hopes of leading a fulfilling life. It is increasingly acknowledged that effective rehabilitation 
delivers better outcomes and improved quality of life and has the potential to reduce health inequalities and make significant cost savings across the health and care system.

Maceh (2018) revealed that rehabilitation covers an enormous spectrum within our patients' pathways. It includes support to learn basic communication skills; exercise classes to improve or maintain optimum health, wellbeing, and occupation; and complex neurological rehabilitation following major trauma or stroke. Rehabilitation may be appropriate at any age as a person's needs change through the course of their life. For example, they may require support to:

- develop skills for the first time;

- recover from unexpected illness;

- manage long-term conditions;

- self-manage conditions;

- recover from major trauma;

- maintain skills and independence;

- access advocacy.

Danke (2019) added that rehabilitation is "a set of measures that assist individuals who experience, or are likely to experience, disability resulting from an impairment, regardless of when it occurred (congenital, early or late) to achieve and maintain optimal functioning in interaction with their environments". The individual in his environment should be the center of the rehabilitation process. "Individuals" should be understood to be not just those "who experience, or are likely to experience, disability," but also their families, who can be helped to become actors in the rehabilitation process and benefit from the results achieved.

\subsubsection{Academic Performance}

Academic performance is the advancement of students going from one phase to another or scores obtained within the course of an examination. (Henderson \& Mapp, 2019). They argue that students' academic performance is usually limited by report cards and grades, grade point averages, enrolment in advanced years, attendance and staying in school, being advanced to the next stage, and improved behaviour. In this study, academic performance refers to score in school examinations.

\subsubsection{Quality of Social Interaction}

The development of social norms is being fostered through the development of a healthy social interaction system. Quality social interaction can discourage the adoption of risky behaviours. Unhealthy habits such as drinking, smoking, stealing, examination malpractice, loitering can be influenced through lack of quality social interaction. In addition, social interactions favour the establishment of mutual assistance mechanisms. In the case of sickness, the support of family, teachers, and peers plays a fundamental role in ensuring that the individual is physically and emotionally supported. Hence social interaction aids in promoting higher levels of happiness and well being 


\section{Theoretical Framework}

\subsection{Ecological/Bio-Ecological Theory}

This study is guided by the ecological systems theory propounded by Urie Bronfenbrenner (1917-2005). According to the theory, children develop within multiple social systems that influence every aspect of their lives including education and interpersonal relationship. Elements within the various systems potentially influence the social confidence and educational outcomes of children with hearing impairment. Bronfenbrenner argued that various immediate and distant forces affect an individual's development. He classified these systems into five; namely, the microsystems, mesosystems, exosystems, macrosystems, and chronosystems in which the first four interact with or are linked together in a system of nested, interdependent, and dynamic structures ranging from the proximal, consisting of immediate face-to-face settings, to the most distal, comprising broader social contexts such as classes and culture (Bronfenbrenner, 1993).

He believed that development involves a reciprocal and dynamic relationship between all these five systems, in which each developing person is significantly affected by interactions between numbers of overlapping systems. The microsystem consists of interpersonal relationships and pattern of activities as experienced by an individual in a given society of specific physical and material features (Bronfenbrenner, 1995). This layer has direct contact with the individual as it contains structures, relationships, and interactions within the person's immediate environment (such as family, school, and neighbourhood) and therefore has the most influence on the individual (Ryan, 2001). The mesosystem directly affects the child and is within the child's immediate environment characterized by direct relationships and interactions. For instance, the rehabilitator, sign language interpreter, or special teacher in the classroom plays a very important role in the school system since he/she is one of the key persons who can help students with hearing impairment.

The last system is the chronosystem, which describes the time frame of development. Swart (2005) described it as a developmental time frame that crosses through and affects the interaction between systems and in turn, their influences on individual development. It is through the interaction among any of the above levels that barriers, support, or restoration may be present at any time. Bronfenbrenner, (1995) further suggested that a change in any part of the system affects other systems and individuals and at a later time could be seen as a cause for change. Elements within this system can be either external, such as the timing of a parent's death; or internal, such as the physiological changes that occur with the aging of a child (Ryan, 2001). This means that the age of onset and detection of hearing loss and even the time made available for studies and rehabilitation (which constitute the chronosystem of students with hearing impairment) can influence their academic performance and quality of social interaction. 


\subsection{Empirical Review}

In a study by Roy and Khar (2012) on disability and rehabilitation services in India: issues and challenges. The researchers noted that hearing disability is an important public health problem especially in developing countries like India. The problem will increase in the future because of the increase in the trend of non-communicable diseases and the change in age structure with an increase in life expectancy. The issues are different in developed and developing countries, and rehabilitation measures should be targeted according to the needs of the disabled with community participation. In India, a majority of the disabled resides in rural areas where accessibility, availability, and utilization of rehabilitation services and their cost-effectiveness are the major issues to be considered. Research on disability burden, appropriate intervention strategies, and their implementation to the present context in India is a big challenge. Recent data was collected from Medline and various other sources and analyzed. The paper discusses various issues and challenges related to disability and rehabilitation services in India and emphasize strengthening health care and service delivery to the hearing disabled in the community.

In addition, Nanjwan and Plang (2014) examined the rehabilitation process and persons with physical dysfunctions. To achieve the purpose of this study, three hypotheses were formulated. An ex-post facto research design was adopted for the study. A sample of one hundred persons with disabilities was randomly selected for the study. The selection was done through the simple random sampling technique. This was to give an equal and independent opportunity to all the respondents to be selected for the study. The questionnaire was the major instrument used for data collection. The instrument was subjected to both face and content validation by experts in measurement and evaluation. The reliability estimate of the instrument was established through the test-retest reliability method Pearson product correlation analysis and independent t-test were employed were adopted to test the hypotheses at .05 level of significance. The result of the analysis reveals that rehabilitation significantly relates to persons with orthopedic and neurological impairments. The result also revealed that there is a significant difference between male and female disabled persons in their perception of rehabilitation of persons with other health impairments.

A similar study by Ewa (2016), on an evaluation of existing rehabilitation service provisions for students with hearing impairment and the conditions necessary for effective implementation of inclusive education programme in Nigeria. To achieve the purpose of this study, five null and one alternate hypothesis were formulated to guide the study. A survey research design was adopted for the study. This design was considered appropriate because it allows the researcher to make inferences and generalization of the population by selecting and studying the sample for the study. Samples of seven thousand four hundred respondents were randomly selected for the study. The selection was done through the simple random sampling technique. This was to give an equal and independent opportunity to all the members of the population to be selected for the study. A four-point Likert-like questionnaire on conditions necessary for 
effective implementation of inclusive education programme for students with hearing impairment in Nigeria (CONEIIEPSWHIN) and executive interview were the main instruments used for data collection.

The instruments were subjected to both face and content validation by the supervisor and experts in measurement and evaluation in the Faculty of Education, University of Calabar. The reliability estimate of the instruments was established through split-half reliability method. The reliability co-efficient from the split-half was corrected with Spearman Brown Prophesy Formula. Pearson Product Moment Correlation Analysis and independent $\mathrm{t}$-test were the statistical analysis techniques adopted to test the hypotheses under study to ascertain whether to reject or retain them. These statistical tools were used because of the nature of the variables involved in the study. All hypotheses were subjected to testing at .05 level of significance with relative degrees of freedom. The results of the analysis revealed that positive/negative attitudes toward students with hearing impairment in the regular secondary schools' environment are not significantly related to effective implementation of inclusive education, while the students with hearing impairment use of Assistive Technology (AT) devices in the inclusive secondary schools, teachers' training in the regular school setting, Government commitment to the course of inclusion of the students with hearing impairment into a regular school setting and the availability of supportive staffs in the regular school environment have a significant relationship with effective implementation of inclusive education programme in Nigeria. The study also revealed that there is no significant difference in the provision of educational service resources between the Northern and Southern geopolitical zones of Nigeria and the effective implementation of inclusive education in Nigeria. Based on the findings of the study, recommendations and suggestions for further studies were made.

Finally, in a study by Andrea and Akil (2016) on stakeholders' perceptions of rehabilitation services for individuals living with disability: a survey study. The researcher noted that the World Health Organization (WHO) was tasked with developing health system guidelines for the implementation of rehabilitation services. Stakeholders' perceptions are an essential factor to take into account in the guideline development process. In their method, disseminated online self-administered questionnaires through a number of international and regional organizations from the different WHO regions. Eligible individuals included persons with disability, caregivers of persons with disability, health professionals, administrators, and policy makers. The answer options consisted of a 9-point Likert scale. The results show that two hundred fifty three stakeholders participated. The majority of participants were health professionals (64\%). In terms of outcomes, 'Increasing Access' and 'Optimizing utilization' were the top service outcomes rated as critical (i.e., 7, 8, or 9 on the Likert scale) by $>70 \%$ of respondents. 'Fewer hospital admissions', 'Decreased burden of care' and 'Increasing longevity' were the services rated as least critical (57\%, $63 \%$, and $58 \%$ respectively). 
In terms of services, 'Community based rehabilitation' and 'Home based rehabilitation' were found to be both definitely feasible and acceptable (75\% and $74 \%$ respectively). 'Integrated and decentralized rehabilitation services' was found to be less feasible than acceptable according to stakeholders (61\% and $71 \%$ respectively). As for 'Task shifting', most stakeholders did not appear to find task shifting as either definitely feasible or definitely acceptable (63\% and $64 \%$ respectively). It was concluded that the majority of stakeholders perceived 'Increasing access' and 'Optimizing utilization' as most critical amongst rehabilitation outcomes. The feasibility of the 'Integrated and decentralized rehabilitation services' was perceived to be less than their acceptability. The majority of stakeholders found 'Task shifting' as neither feasible nor acceptable.

\section{Methodology}

This study adopted the correlational research design. The target population involved in this study consisted of all persons with hearing impairment in Obio/Akpor Local Government Area of Rivers State, Nigeria. A simple random sampling technique was adopted to select a target population of sixty (60) students with hearing impairment. The research instrument, which was the questionnaire, comprised ten (10) items, on a modified 4-point Likert rating scale of (strongly Agree-4 points, Agree-3 points, Disagree 2-points, and strongly disagree 1 point). The respondents were required to indicate their level of agreement for each statement. All the sixty (60) copies of the questionnaire were retrieved, properly filled, and used for the analysis. The data was statistically analysed using mean and standard deviation to answer the research questions while Pearson Product Moment Correlation (PPMC) was used to test the null hypotheses at 0.05 level of significance.

Research Question One: What is the relationship between rehabilitation and academic performance of persons with hearing impairment in Obio/Akpor Local Government Area of Rivers State?

Table 1: Mean and standard deviation showing relationship between rehabilitation and academic performance of persons with hearing impairment in Obio/Akpor Local Government Area of Rivers State (Criterion $\overline{\mathrm{X}}=2.5$ )

\begin{tabular}{|c|l|c|c|c|}
\hline S/N & Items & $\overline{\mathbf{X}}$ & S.D. & Remarks \\
\hline 1 & $\begin{array}{l}\text { Haven received special tutorship, I have witnessed an } \\
\text { accelerated increase in my performance. }\end{array}$ & 3.16 & 0.97 & Accepted \\
\hline 2 & $\begin{array}{l}\text { My performance at the end of examination has increased } \\
\text { drastically due to the impact of rehabilitation service providers. }\end{array}$ & 3.38 & 0.79 & Accepted \\
\hline 3 & $\begin{array}{l}\text { With the support, I receive from my teachers I now have an } \\
\text { enhanced academic performance. }\end{array}$ & 3.08 & 0.95 & Accepted \\
\hline 4 & $\begin{array}{l}\text { The rehabilitation programs designed by my school has brought } \\
\text { about significant increase in my academics. }\end{array}$ & 3.24 & 0.85 & Accepted \\
\hline 5 & $\begin{array}{l}\text { Individualized instruction as a rehabilitation strategy has } \\
\text { enabled me to improve in my academics. }\end{array}$ & 3.08 & 0.82 & Accepted \\
\hline & Cluster mean/Standard Deviation & $\mathbf{3 . 1 9}$ & $\mathbf{0 . 8 8}$ & \\
\hline
\end{tabular}

Source: Survey Data, 2021 
Table 1 shows that items 1, 2, 3, 4, and 5 respectively were all accepted, as the relationship between rehabilitation and academic performance of persons with hearing impairment in Obio/Akpor Local Government Area of Rivers State. The table showed that the mean ratings of items 1-5 are 3.16, 3.38, 3.08, 3.24, and 3.08 respectively with the corresponding standard deviations of $0.97,0.79,0.95,0.85$, and 0.82 . That haven received special tutorship, I have witnessed an accelerated increase in my performance, My performance at the end of examination have increased drastically due to the impact of rehabilitation service providers, With the support, I receive from my teachers I now have an enhanced academic performance, The rehabilitation programs designed by my school has brought about significant increase in my academics, Individualized instruction as a rehabilitation strategy has enabled a to me improve in my academics. The cluster mean of 3.19 with the standard deviation of 0.88 was also found to be above the cut-off point of 2.50. This implies that there is a positive relationship between rehabilitation and academic performance of persons with hearing impairment in Obio/Akpor Local Government Area of Rivers State.

Research Question 2: What is the relationship between rehabilitation and quality of social interaction of persons with hearing impairment in Obio/Akpor Local Government Area of Rivers State?

Table 2: Mean and standard deviation showing the relationship between rehabilitation and quality of social interaction of persons with hearing impairment in Obio/Akpor Local Government Area of Rivers State (Criterion $\bar{X}=2.5$ )

\begin{tabular}{|c|l|c|c|c|}
\hline S/N & Items & $\overline{\mathbf{X}}$ & S.D. & Remarks \\
\hline 6 & $\begin{array}{l}\text { Through rehabilitation, the number of persons in my social } \\
\text { group has increased. }\end{array}$ & 3.03 & 0.97 & Accepted \\
\hline 7 & $\begin{array}{l}\text { I feel more confident interacting with my peers haven witnessed } \\
\text { significant boost in my self-esteem due to rehabilitation. }\end{array}$ & 3.06 & 0.96 & Accepted \\
\hline 8 & $\begin{array}{l}\text { My exposure through rehabilitation has enabled me to develop } \\
\text { good social skills. }\end{array}$ & 3.10 & 0.99 & Accepted \\
\hline 9 & $\begin{array}{l}\text { Through exposure to rehabilitation services, I can now make use } \\
\text { of more assistive devices which impacts on my communication } \\
\text { skills. }\end{array}$ & 3.42 & 0.85 & Accepted \\
\hline 10 & $\begin{array}{l}\text { Through rehabilitation, I now enjoy higher levels of happiness } \\
\text { and wellbeing. }\end{array}$ & 3.22 & 0.91 & Accepted \\
\hline & Cluster mean/Standard Deviation & $\mathbf{3 . 1 7}$ & $\mathbf{0 . 9 4}$ & \\
\hline
\end{tabular}

Source: Survey Data, 2021

Table 2 shows that items 6, 7, 8, 9, and 10 respectively were all accepted, as a relationship between rehabilitation and quality of social interaction of persons with hearing impairment in Obio/Akpor Local Government Area of Rivers State. The table showed that the mean ratings of items $6-10$ are $3.03,3.06,3.10,3.42$, and 3.22 respectively with the corresponding standard deviations of $0.97,0.96,0.99,0.85$, and 0.91 . All the mean ratings are above the cut-off point of 2.50. This means that the respondents agreed that through rehabilitation, the number of persons of in my social group has increased, I feel more confident interacting with my peers haven witnessed a significant boost in my self- 
esteem due to rehabilitation, My exposure through rehabilitation has enabled me to develop good social skills, Through exposure to rehabilitation services, I can now make use of more assistive devices which impacts on my communication skills, through rehabilitation, I now enjoy higher levels of happiness and wellbeing. The cluster mean of 3.17 with the standard deviations of 0.94 was also found to be above the cut-off point of 2.50. This implies that there is a positive relationship between rehabilitation and academic performance of persons with hearing impairment in Obio/Akpor Local Government Area of Rivers State.

Hypothesis One: There is no significant relationship between rehabilitation and academic performance of persons with hearing impairment in Obio/Akpor Local Government Area of Rivers State.

Table 3: Pearson's Product Moment Correlation Showing Relationship between Rehabilitation and Academic Performance of Persons with Hearing Impairment in Obio/Akpor Local Government Area

\begin{tabular}{|c|c|c|c|}
\hline \multicolumn{4}{|l|}{ Correlations } \\
\hline & & Rehabilitation & Academic Performance \\
\hline \multirow[t]{3}{*}{ Rehabilitation } & Pearson Correlation & 1 & $0.505^{* *}$ \\
\hline & Sig. (2-tailed) & & 0.000 \\
\hline & $\mathrm{N}$ & 60 & 60 \\
\hline \multirow[t]{3}{*}{ Academic Performance } & Pearson Correlation & $0.505^{* *}$ & 1 \\
\hline & Sig. (2-tailed) & 0.000 & \\
\hline & $\mathrm{N}$ & 60 & 60 \\
\hline
\end{tabular}

**. Correlation is significant at the 0.05 level (2-tailed).

Table 3 further revealed that the relationship between rehabilitation and academic performance of persons with hearing impairment in Obio/Akpor Local Government Area of Rivers State is significant at 0.05 level. This is because the calculated r-value $(0.505)$ is greater than the table $r$-value (0.195). This implies that the null hypothesis is rejected while the alternate hypothesis is not accepted. The result shows that there is a significant relationship between rehabilitation and academic performance of persons with hearing impairment in Obio/Akpor Local Government Area of Rivers State.

Hypothesis Two: There is no significant relationship between rehabilitation and quality of social interaction of persons with hearing impairment in Obio/Akpor Local Government Area of Rivers State.

Table 4 further revealed that the rehabilitation and quality of social interaction of persons with hearing impairment in Obio/Akpor Local Government Area of Rivers State are significant at 0.05 level. This is because the calculated r-value (0.496) is greater than the table r-value (0.195). This implies that the null hypothesis is rejected while the alternate hypothesis is not accepted. The result shows that there is a significant relationship between rehabilitation and quality of social interaction of persons with hearing impairment in Obio/Akpor Local Government Area of Rivers State. 
Table 4: Pearson's Product Moment Correlation Showing Relationship between Rehabilitation and Quality of Social Interaction of Persons with Hearing Impairment in Obio/Akpor Local Government Area

\begin{tabular}{|l|l|c|c|}
\hline \multicolumn{2}{|l|}{ Correlations } & Rehabilitation & Quality of Social Interaction \\
\hline \multirow{3}{*}{ Rehabilitation } & $\begin{array}{l}\text { Pearson } \\
\text { Correlation }\end{array}$ & 1 & $0.496^{* *}$ \\
\cline { 2 - 4 } & Sig. (2-tailed) & & 0.000 \\
\cline { 2 - 4 } & $\mathrm{N}$ & 60 & 60 \\
\hline \multirow{2}{*}{$\begin{array}{l}\text { Quality of Social } \\
\text { Interaction }\end{array}$} & $\begin{array}{l}\text { Pearson } \\
\text { Correlation }\end{array}$ & $0.496^{* *}$ & 1 \\
\cline { 2 - 4 } & Sig. (2-tailed) & 0.000 & 60 \\
\cline { 2 - 4 } & $\mathrm{N}$ & 60 & \\
\hline
\end{tabular}

**. Correlation is significant at the 0.05 level (2-tailed).

\section{Discussion}

The result of research question one with its corresponding hypothesis (Table, $1 \& 3$ ) reveals that there is a significant relationship between rehabilitation and academic performance of persons with hearing impairment in Obio/Akpor Local Government Area of Rivers State. When Pearson Product Moment Correlation analysis was applied, the (rcal) was 0.505 while (r-tab) was 0.195 at 0.05 level of probability. This indicates that there is a positive relationship between rehabilitation and academic performance of persons with hearing impairment in Obio/Akpor Local Government Area of Rivers State. The result of the study is in tandem with the revelation of Handry (2014) who revealed that rehabilitation which is geared towards the restoration of an individual back to a state of normalcy acts as a powerful tool in the enhancement of the academic performance of students with special needs.

The result of research question two with its corresponding hypothesis (Table, $2 \& 4$ ) reveals that there is a significant relationship between rehabilitation and quality of social interaction of persons with hearing impairment in Obio/Akpor Local Government Area of Rivers State. When Pearson Product Moment Correlation analysis was applied, the (rcal) was 0.496 while (r-tab) was 0.195 at 0.05 level of probability. This indicates that there is a positive relationship between rehabilitation and quality of social interaction of persons with hearing impairment in Obio/Akpor Local Government Area of Rivers State. The findings collaborate with the observation of Mendy (2015) who acknowledged that for students with hearing impairment to fit properly into their educational, vocational, and social environment, there must be the practice of a rehabilitation service/program in place. Mendy (2015) added that rehabilitation promotes the level of students' social participation, interaction, and activity wellbeing. 


\section{Findings}

Based on the findings of the study, the researcher reveals that: there is a significant relationship between rehabilitation and academic performance of persons with hearing impairment in Obio/Akpor Local Government Area of Rivers State. And that there is significant relationship between rehabilitation and quality of social interaction of persons with hearing impairment in Obio/Akpor Local Government Area of Rivers State.

\section{Conclusion}

Rehabilitation is essential for the total restoration of students with hearing impairment as such service that will enhance the academic performance, and social interaction of students with hearing impairment as well as other forms of disability should be passionately pursued.

\subsection{Implications of the Study for Special Needs Counselling}

The results of the study have serious implications for Special Needs Counselling. This result has the implication for special counselling services to be provided at all levels of education. This will enable students with hearing impairment as well as other areas of disability to seek assistance that will enable them to realize and maximize their potential.

The implication of the study has necessitated the need for institutions responsible for the training of counsellors to include in their curriculum 'special needs counselling' to prepare them in the task of complementing the effort of special educators, rehabilitators, and other professionals in the total restoration of students with hearing impairment.

Another implication of this study is the need to make counselling services functional at all levels of education. It is not enough to establish counselling services in general and special schools but to make it functional by providing all the needed facilities and equipment that will enhance the capacity of the counsellors in discharging their functions effectively towards the rehabilitation of students with hearing impairment.

\section{Recommendations}

Based on the findings of this study, the following recommendations were made:

1) The practice of inclusive education under the Universal Basic Education (UBE) programme in Nigeria should not only be in theory but should translate into practice where all the necessary facilities and resources are put in place for the utmost development of the special needs students in general and students with hearing impairment in particular to contribute his or her quota to the full development of a just and egalitarian society in Nigeria.

2) Multi-disciplinary approach should be adopted in rehabilitation service delivery to students with hearing impairment. Support staff should work as a team with 
other personnel for the successful restoration of students with special needs in Nigeria.

3) Diverse and specialized professional development options must be provided that will allow for teachers/supportive staff to gain experiences that can help meet the needs of the students with impaired hearing.

4) Government should show commitment to rehabilitation programs through adequate budget and funding of the programme.

\section{Conflict of Interest Statement}

We, the authors whose names are listed below hereby disclose that we have no conflict of interest to declare and other potentially affiliation with or involvement in any organization or entity, including specifics or non-financial interest, relationships and affiliations in the subject matter or materials discussed in the manuscripts that could interfere with the publication of the article "Rehabilitation of Persons With Hearing Impairment in Obio/Akpor Local Government Area of Rivers State, Nigeria: Implication for Special Needs Counselling" submitted and published under European Journal of special needs education.

\section{About the Authors}

Ubani Samuel N. (PhD) is a lecturer with Ignatius Ajuru University of Education, Port Harcourt, Rivers State, Nigeria. He lectures under the Department of Educational Psychology, Guidance and counselling with specialty on special needs education of the hearing impaired. His research centers on educational inclusiveness and rehabilitation of persons with hearing impairment in a formal and non-formal setting. He has contributed widely in local and international journals; he authored several books on Special needs Education and contributed in book chapters. His passion is on rehabilitation counselling for persons with disabilities in Rivers State, Nigeria.

Dr. Ngozi Okiridu is a staff of Ignatius Ajuru University of Education Port Harcourt, Nigeria in the field of Educational Psychology, Guidance and Counselling (Option Special Needs Education). She holds a Doctorate degree in special needs education with exceptional flair on education of persons with hearing impairment. She is passionate about the education of girls with disabilities and her dream is to see that they obtain the required education which is their right, with minimum or nor discrimination.

Iroegbu Ferdinand Favour holds a Master degree in Special Needs Education from Ignatius Ajuru University of Education Port Harcourt, Nigeria in the department of Educational Psychology, Guidance and Counselling (Option Special Needs Education). She is an educationist and administrator of Cherry Pearl Foundation which is a school poised at promoting all aspect of inclusiveness and integration of persons with disabilities into the society. 


\section{References}

Andrea, M., \& Akil, D. (2016), Developing policies for inclusive education: A study of the role of local education authorities. International journal of inclusive education 28 (1), 24-29

Danke, U. (2019). Special and general education teachers' perspective on rehabilitation. Psychology and Health, 18(4), 489-500.

Dunlop, P. (2005). Inclusive education for students with disabilities: Benefits, challenges and policy. International journal of special education 23 (3).

Ewa, M. (2016). An empirical study on teachers' perception toward inclusive education in Malaysia. International journal of special education, 21 (3), 36-44.

Handry, M. M. (2014). Programmes and services development for persons with Hearing impairment. Journal of exceptional children (NCEC). 6 (2) 42-49.

Henderson, W. \& Mapp, T. (2019). Toward inclusive rehabilitation: Journal of Abnormal and Social Psychology, 66(6), 574-583.

Iheanacho, M. (2010). Inclusive education for persons with disabilities: General overview. African journal of special education needs IV (1).

Maceh, E. L. (2018). Basic psychological needs in motivation, development, and wellness. Guilford Press.

Mendy, B. A. (2015). Families that work for the Hearing impaired child. The volta review, 87 (3), 131-137.

Nanjioan, A. \& Plang T. (2014). Special needs in the twenty first century: where have we been and where we're going (The Ron Gulliford lecture) Journal of special education, $28(1), 24-49$.

Obani, T. C. (2006). Special education and special educational needs. In T. C. Obani (Ed) teaching pupils with special educational needs in the regular UBE classroom. Book-builders. 37-68.

Ozoji, E. D. (1993). Special education for the nonprofessional. Deka publications.

Ozoji, E. D. (2003). Contemporary programmes for educating special needs children in the 21st century. In E. D. Ozoji (Ed) Updates in educating special needs children in the regular school. Deka publications.

Roy, S. \& Khar U. (2012). The illustrated guide to Assistive technology and devices: Tools and gargets for living independently. Demos Health.

Ryan, W. (2001). Reflection. In T. M. Skrtic, E. M. Horn \& G. M. Clark (Eds) Taking stock of special education policy and practice: A retrospective commentary. Love publishing, 467-468.

Sari G. (2015). The impact of inclusion on students with and without disabilities and their educators: Remedial and special education 20 (2) 114- 126.

Swart A. (2005). Teacher perceptions of mainstreaming/inclusion: A research synthesis. Exceptional children 63 (1) 59-74

Ubani S. N., Osuagwu C. E., Ogbonna P., \& Tanu T. A. (2019). Barriers to counselling children with special needs education. In Inclusion, equality, support and 
sustainability development. Elemukan S. Ugo A.E (eds.). National association for exceptional children.

Kinanee J. B. \& Ubani S. N. (2020). Introduction to the field of special education. Counselling and human development in Nigeria. Readings in honour of prof. Ibrahim Adamu Kolo. Egbochuku E.O, Ifelunni C.S. (Eds.). Counselling association of Nigeria.

Ubani S. N., Bright-George J. W., Otunya M., Ifezue N. J., \& Okiridu N. (2020). Care and support for sustainable development of children with special needs. Adaka T.A., Oguntunde A. G., Abdulrahman A. (eds). Issues, theories and practice in education. Nats printing and publishing enterprise

Ubani S. N. \& Sanikpege H. T. (2020). Foundations of special needs education. Premium service ventures.

Creative Commons licensing terms

Authors will retain the copyright of their published articles agreeing that a Creative Commons Attribution 4.0 International License (CC BY 4.0) terms will be applied to their work. Under the terms of this license, no permission is required from the author(s) or publisher for members of the community to copy, distribute, transmit or adapt the article content, providing a proper, prominent and unambiguous attribution to the authors in a manner that makes clear that the materials are being reused under permission of a Creative Commons License. Views, opinions and conclusions expressed in this research article are views, opinions and conclusions of the author(s). Open Access Publishing Group and European Journal of Special Education Research shall not be responsible or answerable for any loss, damage or liability caused in relation to/arising out of conflict of interests, copyright violations and inappropriate or inaccurate use of any kind content related or integrated on the research work. All the published works are meeting the Open Access Publishing requirements and can be freely accessed, shared, modified, distributed and used in educational, commercial and non-commercial purposes under a Creative Commons Attribution 4.0 International License (CC BY 4.0). 